\title{
Prevalence of Human Papilloma Virus in the Oral Cavity of a Mexican Sample FG Villanueva Sánchez ${ }^{1}$, LA Gaitán Cepeda ${ }^{2}$
}

\author{
Affiliations: \\ Correspondence: \\ Dr L Gaitan Cepeda \\ Lab de Patologia Clinica y Experimental, DEPL, Fac \\ Odontologia, UNAM \\ Circuito Institutos s/n, Ciudad Universitaria \\ Coyoacan $\mathrm{O} 4510$ \\ DF, Mexico \\ Fax: +52(55)56225559/60 \\ E-mail: Igaitan@unam.mx
}

${ }^{1}$ Oral Diagnosis Clinic, Faculty of Dentistry, Juárez University of Durango State, Mexico

${ }^{2}$ Laboratory of Clinical and Experimental Pathology, Graduate and Research Division, Dental School, National Autonomous University of Mexico, Mexico city, Mexico.

Short title: Oral HPV in Mexicans

Synopsis: This paper, whose main objective was to assess HPV prevalence in oral mucosa of Mexicans attending in a teaching clinic, shows a high prevalence (35.4\%) of HPV in Mexican population, principally in males who smoke marijuana or have oral sex. 


\section{ABSTRACT}

Objective: To assess the prevalence of oral HPV in a Mexican sample and to establish their possible association to socio-demographical characteristics, habits and/or sexual behavior. Methods: 110 consecutive patients atending in an Oral Medicine and Pathology teaching clinic were orally examined and applied a questionnaire concerning demographical characteristics, habits and sexual behavior. At this moment a cytobrush scraping of buccal mucosa was taken and immediately immersed in $80 \%$ ethanol, transported to laboratory and centrifuged to obtain a supernatan. HPV identification was made through immunohistochemistry technique using antibody anti-HPV while confirmation of HPV presence and their typífication was done using MY09/11 and GP5+/6+ PCR technique. Possible associations of socio-demographical and sexual behavior variables with HPV infection were establish usng chi square test ( $\mathrm{p}<0.05$; 95\% IC). Results: 39 (35.4\%) patients were HPV-positive, most of them at their 5th decade of life; $74.3 \%$ of HPV-positive were smokers; $43.5 \%$ intakes alcoholic beverages and $25.6 \%$ were marihuana smokers. Their age of onset of sexual life was at 17 years old (Standar Deviation \pm 6.64 ), while $59 \%$ were sexually active and $64.1 \%$ actually practice oral sex. Statistical association of HPV positive male with oral sex (p 0.01) and with smoke marihuana (p 0.04) was establish. HPV13 was the most common HPV subtype identified; HPV53, HPV45 and HPV11 were identified too. Only Six of 39 HPV-positive patients presents HPV clinical lesion: 4 oral papilloma and 2 condiloma acuminata.

Conclusions: Mexican population show high HPV oral infection, specifically male who practice oral sex or smoke marihuana.

Keywords: Human papilloma virus, oral cavity, oral lesions, papiloma, sexual transmited disease. 


\section{INTRODUCTION}

Human papiloma virus (HPV) is an epitheliotrophic and dermatrophic DNA virus which has been identified more than 100 subtypes (1). Due to the close relation existing between genital HPV infection and cervical cancer, HPV subtypes $6,11,41,43$, and 44 have been classified as low risk for developing malignancies. HPV subtypes 16,18,31,33,35,39,45,46,51,52 have been classified as high risk for developing malignancies (1), specifically 16,18 HPV subtypes have been attributed an oncogenic role in the development of oral squamous cell carcinoma $(2,3)$. Consequently drawing scientific interest in HPV infection associated to head and neck cancers. However the prevalence, risk factors and demographic profile of patients suffering oral HPV infection, specifically subjects without oral clinical lesion, remain scarce, unconclusive or even unknown. Therefore the principal objective of this paper is to assess the prevalence of HPV in oral mucosa of a Mexican sample attending in an oral medicine and oral pathology teaching clinic, and additionaly to assess if HPV oral infection in this Mexican sample is related to demographical characteristics, habits or sexual behavior.

\section{MATERIAL AND METHODS}

The present project adhered to research parameters established by the Mexican General Health Law, article 17, fraction I (4). This research was considered of low risk to patient, and the protocol research was approved by the Bioethical Comittee of the Dental School, National Autonomous University of Mexico, and it was conducted in full accordance with the World Medical Association Declaration of Helsinski.

A cross-sectional study consisting of 110 consecutive patients, $\geq 18$ years old, regardless of gender, atending for first time the Oral Medicine and Oral Pathology clinic, Graduate Division, 
Dental School, National Autónomos University of México, México city, from march of 2011 to December of 2012, was conducted. The patients were recruited for the study after a valid informed consent had been obtained, which ensured confidentiality in data handling and the possibility to withdraw from the study at any moment. At moment of their enrollenment a questionnaire concerning demographical characteristics (gender, age), habits (tobacco use, alcoholism, use of recreative drugs), and sexual behavior (age at first sexual experience, number of sexual partners, oral sex practice, use of condom) was conducted. In the case of tobacco use, alcoholism and use of recreative drugs, patients were categorized as "positive" that included active habit and "negative" that included patients who never had practiced the habit and formers (ex) consumers.

As part of their clinical protocol, all patients were orally examined by two experts in oral pathology and oral medicine (FGVS/LAGC). If necessary, clinical diagnoses were histopathologically corroborated. At this clinical moment oral scrapings were taken using a small brush from the buccal mucosa and dorsal surface of the tongue. All oral samples were collected by same person (FGVS). Immediatelly after the scrap, the cytobrush was immersed in $80 \%$ ethanol (preservCyt) to be transported to the laboratory of Clinical and Experimental Pathology, at same institution. In the laboratory all samples were centrifuged, the supernatant obtained was dividided in two samples: sample A was destined to immunohistochemistry technique; while sample B was frozen and stored at $-70^{\circ} \mathrm{C}$ to be destined to PCR technique to obtain HPV DNA.

\section{Immunohistochemistry assay}

The immunohistochemistry technique was conventionally performed, in summary: after primary antibody incubation, samples were rinsed and incubated in the secundary anti-HPV antibody 
(®BIO Science). The homologous sample (sample B) of samples with immunoreactions antiHPV-positive was destined to confirm HPV infection using PCR technique.

The PCR HPV assay was performed at Laboratory of Stomatology, Faculty of Dentistry, Juárez University of Durango State, Mexico, as follows:

\section{PCR HPV assay}

DNA extraction was performed using Wizard Genomic DNA Purification kit (Promega/WI, USA®). DNA integrity was corroborated using PCR technique to GAPDH amplification. GAPDH F-CAT CTC TGC CCC CTC TGC TGA and R-GGA TGA CCT TGC CCA CAG CCT oligonucleotides were used to amplify a fragment of $305 \mathrm{pb}$ and $400 \mathrm{ng}$ of DNA.

HPV typification was assessed by using MY09/11 and GP5+/6+ PCR, using the specific primers: MY09-CGT CCM ARR GGA WAC TGA TC and MY11-GCM CAG GGW CAT AAY AAT GG oligonucleotides which hybridize L1 region of HPV to obtain an amplicon of $450 \mathrm{pb}$. For GP PCR, the following oligonucleotides were used GP5+-TTT GTT ACT GTG GTA GAT ACT AC and GP6+-GAA AAA TAA ACT GTA AAT CAT ATT C that hybrids MY region, to obtain an amplicon of $150 \mathrm{pb}$. The positive samples to GP were purified with Shrimp Alkaline Phosphatase (SAP) and Exonuclease I (ExoI $\left.{ }^{\circledR}\right)$ enzymes (Thermo Scientific $\left.®\right)$ ). For HPV typification $2.5 \mu \mathrm{L}$ of purified PCR-GP, $1 \mathrm{X}$ of sequencing buffer, $1.0 \mu \mathrm{L}$ of mix Big Dye terminator v3.1 cycler and $0.3 \mathrm{pMol}$ of GP5+ oligonucleotide was used. Labeling reaction was precipitated with $1.0 \mathrm{M}$ of $\mathrm{CH} 3 \mathrm{COONa} \mathrm{pH} 5.2$ and $85 \%$ ethanol. The supernatant was dried on Vacufuga (Eppendorf®, Hamburg, Germany) for $25 \mathrm{~min}$ at $30^{\circ} \mathrm{C}$. Pellet was resuspended in $20 \mu \mathrm{L}$ of formamid to be process in ABI Prims ${ }^{\circledR} 3100$ (Thermo Fisher Scientific, Mass, USA). Chromatogramars were analyzed using Chromas Pro v1.6 software ${ }^{\circledR}$ (Technelysium Pty Ltd, 
QLD, Australia) while HPV typification was assessed using a BLAST of chromatogrammars in the data base of PubMed GenBank.

\section{Statistical analysis}

A descriptive and bivariate analysis were used to establish possible association of sociodemographical data, sexual behavior, alcohol intake, tobacco use and smoking marihuana to HPV infection using chi square test $\left(\mathrm{p}<0.05_{\mathrm{I}} 95 \%\right)$. The software program SPSS ${ }^{2} 20.0$ (IBM, NY, USA) was used.

In cases with clinical oral lesion diagnosis was corroborated by histopathological analyses and specific treatment was established. All HPV positive patients, with or without clinical oral lesions, were informed to emphasize a close follow up by the next year.

\section{RESULTS}

The frequency and relative frequency of demographical characteristics, habits and sexual behavior of whole sample are shown in table 1. From 110 patients included (66 female; 44 male; age mean 48.1 years StandarDeviation $(\mathrm{SD}) \pm 17.7$; range 18 - 83 years) 39 were HPV-positive which is a prevalence of $35.4 \%$. Most HPV-positive cases were at their 5th decade of life. With respect to demographical characteristics, habits or concern to sexual behavior, no statistically significant association was found with HPV-positive ( $p>0.05$ in all cases). However the prevalence of marihuana smokers in HPV- positive subjects was $81.5 \%$ higher than that observed in HPV-negative subjects $(25.6 \%$ vs $14.1 \%)$ and sexual partners average is $300 \%$ higher in HPV-positive subjects than HPV-negative patients (24.2\% vs 5.7\%). 
With respect to gender and HPV infection, comparison of HPV-negative women vs HPVpositive women was not statistically significant to any variable (Table 2). On the other hand HPV-positive males showed statistical significant association to oral sex (p 0.04) and to marihuana smoking (p 0.04) (table 2). More over males who practice oral sex have 6.9 (OR 6.9 IC 1.3-36.5) folds more risk to oral HPV infection and 4.2 folds (OR 4.2 IC 1-17) more risk if he is a marihuana consumer.

In regard to HPV subtypes 21 samples corresponded to HPV13; 9 were HPV53; 4 belonged to subtype HPV45 and two samples corresponded to HPV11. Tree samples were dischargerd by technical reasons.

Six of 39 HPV-positive patients presented oral lesions associated to HPV infection. After histopathological analyses 4 were diagnosed as having oral papilloma and 2 were diagnosed as suffering condiloma acuminata.

\section{DISCUSSION}

The present report, to our knowledge, shows for the first time the prevalence of HPV oral infection in a non- oral cancerous Mexican population. We obtained a prevalence of $34.5 \%$ for all HPV subtypes. HPV prevalence reported in scientific literature is wide, ranging from $0.67 \%$ reported in Chinese (5); 6.9\%-16\% in Americans (6,), to $24.6 \%$ in Vietnamese (7). This data suggest that Mexican population possesses the highest oral HPV prevalence reported. To date we lack any explanation to justify these data, however it seems likely that age, gender, risk factors, ethnicity and even a history of HPV immunization could play an important role. The risk factors to HPV oral infection including: lifetime, oral sex, number of sexual partners, tobacco smoking, 
marihuana consumption and concomitant genital HPV infection (6,8). Americans shows a bimodal pattern of oral HPV infection, a first peak is observed in 30 - 34 years old and the second higher peak is observed in 60 to 64 years old $(6,9)$. In the present report most of HPV-infected patients were at fifth and seventh decade of life, agrees to the aforementioned data. It has been suggested that the second peak could arise from reactivation of latent infections associated to age-related loss of immunity $(7,9)$.

HPV prevalence is closely associated to number of sexual partners $(6,8,10)$. Americans with sexual experience shows 8-fold higher prevalence of HPV-oral infection than subjects who did not reported any sexual activity $(6,8,10)$. In the present report, sexual behavior, except oral sex and males, was very similar in both non-infected and HPV-infected patients $(\mathrm{p}>0.05)$. Even more, HPV-positive subjects showed lower values in variables considered like protective, use of condom at vaginal intercourse and use of condom during oral sex, than oral HPV-negative patients. With respect to habits, women heavy smokers, as well as heavy drinkers and marihuana consumers show high prevalence of oral HPV $(6,10)$. Our results support this assumption because the association of oral HPV and marihuana smokers was statistically significant $(\mathrm{p}<0.05)$.

In Mexican males we obtained a prevalence of $34 \%$ while reported data ranged from $10.1 \%$ (7) to $20 \%$ in male attending in a STD clinic (11). In Mexican female we obtained a prevalence of $36.3 \%$, higher than reported in the 2009-2010 USA National Health Survey: $3.6 \%$ $(6,9)$. The research design of present study did not include knowledge of wheter enrolled women suffered HPV genital infection at moment of oral examination. Due to this lack we cannot rule out a cross infection as likely justification to the high prevalence found in women studied. A Mexican study of women suffering cervical intrepithelial neoplasia found $100 \%$ of oral HPV prevalence (12). However an Australian study failed to establish association of genital HPV and oral HPV (13). 
HPV16, a high risk HPV subtype, is the most frequent genotype to cause oral HPVinfection (5-7). Their prevalence ranged from $0.43 \%$ in Chinese (5) to $16.7 \%$ in Vietnamese (7).

Our findings disagree with this assumption. In the present report HPV13, that cause oral epithelial multifocal hyperplasia, was the most frequent subtype identified. This disease presents high frequency among native American people including Mexicans and it has been associated with ethnicity (14). The fact that none patient orally infected with HPV13 did not presented clinically lesions associated to oral epithelial multifocal hyperplasia confirm the assumption of "healthy oral HPV carriers".

\section{CONCLUSION}

Oral HPV infection is high in Mexican population (35.4\%), regardless gender. Mexican males who smoked marihuana or males who practiced oral sex possess high risk to develop oral HPV infection. The investigation of the prevalence and risk factors for oral HPV infection is the basis for the development of prophylactic strategies. In such a way the high prevalence found by us as well as the fact that none of the patients enrolled in this study were vaccinated against HPV, make it necessary to explore the possibility, feasibility and viability of increasing anti-HPV vaccination campaigns. It could be suggested that, in the event that the vaccine will be effective in preventing HPV oral infection, the HPV vaccine should be administered before the initiation of oral sex by Mexican males. 


\section{AUTHOR'S NOTE}

Dr. Villanueva Sanchez was responsible for conducting clinical inspection of patients and the development of techniques used to obtain data; he wrote the paper and review successive versions, he approved the final version.

Dr. Gaitán Cepeda conceived and planned the work and he interpreted the evidence it present. Dr. Gaitan contributes to clinically review of patients involved and he wrote the paper and review successive versions, he approved the final version. 


\section{REFERENCES}

1. Pattanshetty S, Kotrashetti VS, Nayak R, Bhat K, Somannavar P, Babji D. PCR based detection of HPV 16 and 18 genotypes in normal oral mucosa of tobacco users and nonusers. Biotech Histochem 2014; 89: 433-9.

2. Zhou J, Tao D, Tang D, Gao Z. Correlation of human papilloma virus with oral squamous cell carcinoma in Chinese population. Int J Clin Exp Med 2015; 8: 18172-8.

3. Shaikh MH, McMillan NA, Johnson NW. HPV-associated head and neck cancers in the Asia Pacific: A critical literature review \& meta-analysis. Cancer Epidemiol 2015; 39: 923-8.

4. Reglamento de la Ley General de Salud en Materia de Investigación para la Salud. Articulo 17. Comisión Nacional de Bioética, Secretaría de Salud, México. México; 2012. (cited 17 May 2016). Available from: http://www.conbioeticamexico.salud.gob.mx/descargas/pdf/normatividad/normatinacional/10._NAL._Reglament o_de_Investigacion.pdf).

5. Hang D, Liu F, Liu M, He Z, Sun M, Liu Y et al. Oral human papillomavirus infection and its risk factors among 5,410 healthy adults in China, 2009-2011. Cancer Epidemiol Biomarkers Prev 2014; 23: 2101-10.

6. Gillison ML, Broutian T, Pickard RK, Tong ZY, Xiao W, Kahle L et al. Prevalence of oral HPV infection in the United States, 2009-2010. JAMA 2012; 307: 693-703.

7. Bui TC, Tran LT, Markham CM, Huynh TT, Tran LT, Pham VT et al. Self-reported oral health, oral hygiene, and oral HPV infection in at-risk women in Ho Chi Minh City, Vietnam. Oral Surg Oral Med Oral Pathol Oral Radiol 2015; 120: 34-42.

8. Chung CH, Bagheri A, D'Souza G. Epidemiology of oral human papillomavirus infection. Oral Oncol 2014; 50: 364-9. 
9. Steinau M, Hariri S, Gillison ML, Broutian TR, Dunne EF, Tong ZY et al. Prevalence of cervical and oral human papillomavirus infections among US women. J Infect Dis 2014; 209: $1739-43$.

10. Chaturvedi AK, Graubard BI, Pickard RK, Xiao W, Gillison ML et al. High-risk oral human papillomavirus load in the US population, national health and nutrition examination survey 2009-2010. J Infect Dis 2014; 210: 441-7.

11. Colon-López V, Quiñones-Avila V, Del Toro-Mejías LM, Reyes K, Rivera ME, Nieves $\mathrm{K}$, et al.: Oral HPV infection in a clinic-based sample of Hispanic men. BMC Oral Health 2014; 14: 7. doi: 10.1186/1472-6831-14-7.

12. Sánchez-Vargas LO, Díaz-Hernández C, Martinez-Martinez. A detection of human papilloma virus (HPV) in oral mucosa of women with cervical lesions and their relation to oral sex practices. Infect Agent Cancer 2010; 5: 25. doi: 10.1186/1750-9378-5-25.

13. Meyer MF, Huebbers CU, Siefer OG, Vent J, Engbert I, Eslick GD et al.: Prevalence and risk factors for oral human papillomavirus infection in 129 women screened for cervical HPV infection. Oral Oncol 2014; 50: 27-31.

14. Said AK, Leao JC, Fedele S, Porter SR. Focal epithelial hyperplasia - an update. J Oral Pathol Med 2013; 42: 435-2. 
Table 1: Comparison of socio-demographic characteristics and sexual behavior between hpv+ and hpv-Mexicans

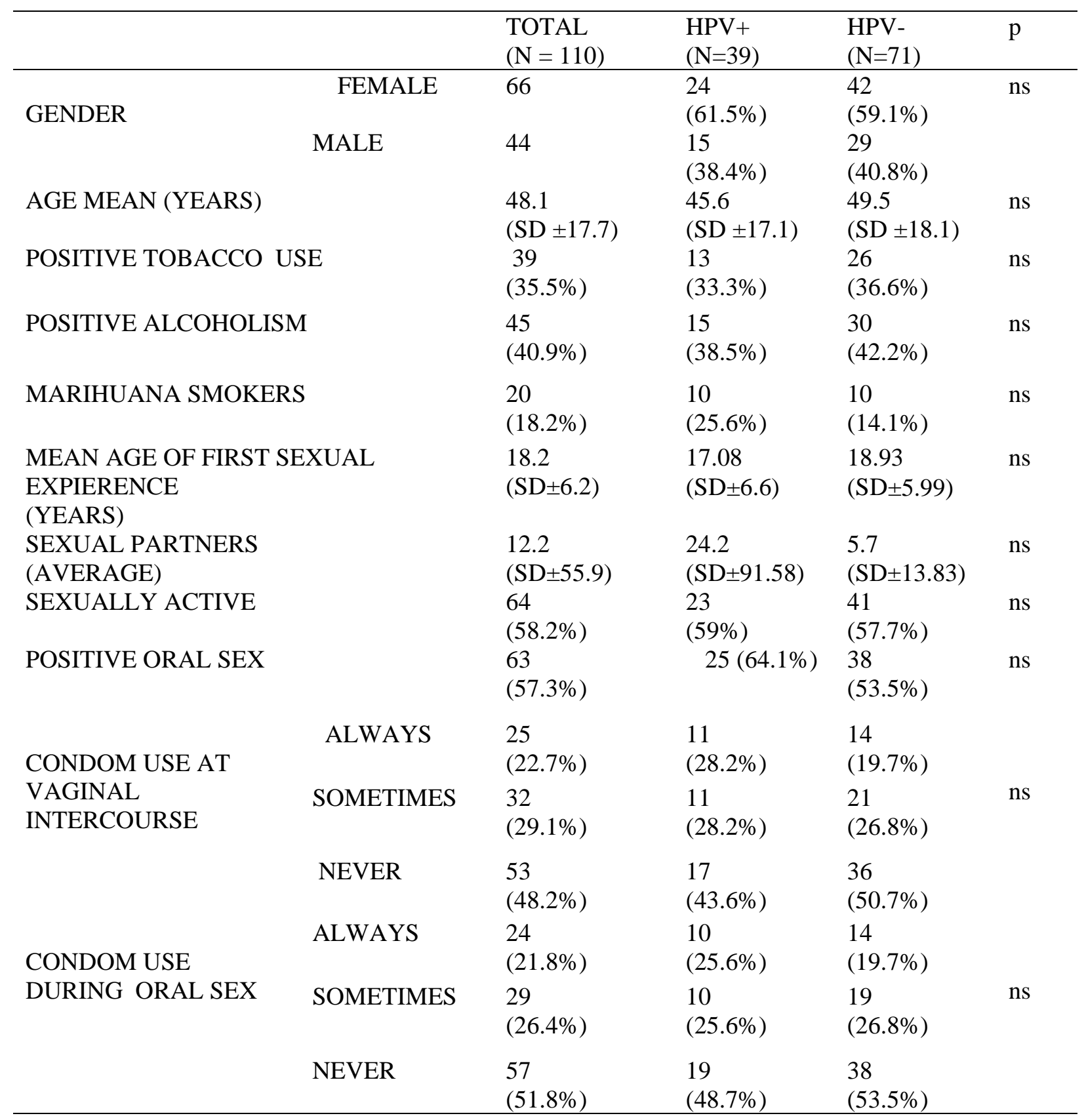

$(\%)=$ relative frequency; $\mathrm{p}=$ chi square value; $\mathrm{ns}=$ no significative; $\mathrm{SD}=$ standar deviation 
Table 2: Comparison of habits and sexual behavior of hpv+ versus hpv- subjects in respect to gender

\begin{tabular}{|c|c|c|c|c|c|c|c|}
\hline \multirow{2}{*}{\multicolumn{2}{|c|}{ HABITS }} & \multicolumn{3}{|c|}{$\begin{array}{l}\text { FEMALES } \\
(\mathrm{N}=66)\end{array}$} & \multicolumn{3}{|l|}{$\begin{array}{l}\text { MALES } \\
(\mathrm{N}=44)\end{array}$} \\
\hline & & $\begin{array}{l}\mathrm{HPV}+ \\
(\mathrm{N}=24)\end{array}$ & $\begin{array}{l}\text { HPV- } \\
(\mathrm{N}=42)\end{array}$ & $\mathrm{p}$ & $\begin{array}{l}\mathrm{HPV+} \\
(\mathrm{n}=15)\end{array}$ & $\begin{array}{l}\text { HPV- } \\
(n=29)\end{array}$ & $\mathrm{p}$ \\
\hline \multicolumn{2}{|c|}{ POSITIVE TOBACCO USE } & $\begin{array}{l}4 \\
(16.7 \%)\end{array}$ & $\begin{array}{l}12 \\
(28.6 \%)\end{array}$ & ns & $\begin{array}{l}9 \\
(60 \%)\end{array}$ & $\begin{array}{l}14 \\
(48.3 \%\end{array}$ & ns \\
\hline \multicolumn{2}{|c|}{ POSITIVE ALCOHOLISM } & $\begin{array}{l}4 \\
(16.7 \%)\end{array}$ & $\begin{array}{l}12 \\
(28.6 \%)\end{array}$ & ns & $\begin{array}{l}11 \\
(73.3 \%)\end{array}$ & $\begin{array}{l}18 \\
(62.1 \%)\end{array}$ & ns \\
\hline \multicolumn{2}{|c|}{$\begin{array}{l}\text { POSITIVE MARIHUANA } \\
\text { SMOKERS }\end{array}$} & $\begin{array}{l}3 \\
(12.5 \%)\end{array}$ & $\begin{array}{l}5 \\
(11.9 \%)\end{array}$ & ns & $\begin{array}{l}7 \\
(46.7 \%)\end{array}$ & $\begin{array}{l}5 \\
(17.2 \%)\end{array}$ & $\begin{array}{l}0.04 \\
\text { OR } 4.2 \\
(\mathrm{CI} 1-17)\end{array}$ \\
\hline \multicolumn{8}{|c|}{ SEXUAL BEHAVIOR } \\
\hline \multicolumn{2}{|c|}{$\begin{array}{l}\text { POSITIVE SEXUALLY } \\
\text { ACTIVE LIFE* }\end{array}$} & $\begin{array}{l}11 \\
(45.8 \%\end{array}$ & $\begin{array}{l}25 \\
(59.5 \%)\end{array}$ & ns & $\begin{array}{l}12 \\
(80 \%)\end{array}$ & $\begin{array}{l}16 \\
(55.2 \%)\end{array}$ & ns \\
\hline \multicolumn{2}{|c|}{ POSITIVE ORAL SEX* } & $\begin{array}{l}12 \\
(50 \%)\end{array}$ & $\begin{array}{l}24 \\
(57.1 \%)\end{array}$ & ns & $\begin{array}{l}13 \\
(86.7 \%)\end{array}$ & $\begin{array}{l}14 \\
(48.3 \%)\end{array}$ & $\begin{array}{l}0.01 \\
\text { OR } 6.9 \\
\text { (CI1.3 - } \\
36.5)\end{array}$ \\
\hline \multirow{3}{*}{$\begin{array}{l}\text { CONDOM USE } \\
\text { AT VAGINAL } \\
\text { INTERCOURS } \\
\text { E }\end{array}$} & ALWAYS & $\begin{array}{l}5 \\
(20.8 \%)\end{array}$ & $\begin{array}{l}5 \\
(11.9 \%)\end{array}$ & ns & $\begin{array}{l}6 \\
(40.4 \%)\end{array}$ & $\begin{array}{l}9 \\
(31.0 \%)\end{array}$ & ns \\
\hline & $\begin{array}{l}\text { SOMETIME } \\
\mathrm{S}\end{array}$ & $\begin{array}{l}6 \\
(25.0 \%)\end{array}$ & $\begin{array}{l}11 \\
(26.2 \%)\end{array}$ & & $\begin{array}{l}5 \\
(33.3 \%)\end{array}$ & $\begin{array}{l}10 \\
(34.5 \%)\end{array}$ & \\
\hline & NEVER & $\begin{array}{l}13 \\
(54.2 \%)\end{array}$ & $\begin{array}{l}26 \\
(61.9 \%)\end{array}$ & & $\begin{array}{l}4 \\
(26.7 \%)\end{array}$ & $\begin{array}{l}10 \\
(34.5 \%)\end{array}$ & \\
\hline \multirow{3}{*}{$\begin{array}{l}\text { CONDOM USE } \\
\text { DURING } \\
\text { ORAL SEX }\end{array}$} & ALWAYS & $\begin{array}{l}5 \\
(20.8 \%)\end{array}$ & $\begin{array}{l}6 \\
(14.3 \%)\end{array}$ & ns & $\begin{array}{l}5 \\
(33.3 \%)\end{array}$ & $\begin{array}{l}8 \\
(27.6 \%)\end{array}$ & $\mathrm{ns}$ \\
\hline & $\begin{array}{l}\text { SOMETIME } \\
\mathrm{S}\end{array}$ & $\begin{array}{l}6 \\
(25.0 \%)\end{array}$ & $\begin{array}{l}10 \\
(23.8 \%)\end{array}$ & & $\begin{array}{l}4 \\
(26.7 \%)\end{array}$ & $\begin{array}{l}9 \\
(31.0 \%)\end{array}$ & \\
\hline & NEVER & $\begin{array}{l}13 \\
(54.2 \%)\end{array}$ & $\begin{array}{l}26 \\
(61.9 \%)\end{array}$ & & $\begin{array}{l}6 \\
(40 \%)\end{array}$ & $\begin{array}{l}12 \\
(41.4 \%)\end{array}$ & \\
\hline
\end{tabular}

$(\%)=$ relative frequency; $\mathrm{p}=$ chi square value; $\mathrm{ns}=$ no significative $; \mathrm{OR}=$ odds ratio; $\mathrm{CI}=$ confidence intervals; ${ }^{*}=$ at moment of oral examination. 